\title{
Environmentally sustainable perioperative medicine: simple strategies for anesthetic practice
}

\author{
Maria-Alexandra Petre, MD, FRCPC (1) - Stephan Malherbe, MBChB, FRCPC, MMed
}

Received: 9 April 2019/Revised: 3 December 2019/Accepted: 30 January 2020/Published online: 8 June 2020

(C) Canadian Anesthesiologists' Society 2020

\begin{abstract}
Purpose This continuing professional development module aims to inform anesthesiologists about the magnitude of healthcare-related waste and its contribution to global warming, as well as providing general strategies to improve environmental sustainability in daily anesthesia practice in a Canadian context.

Principal considerations Global warming is considered to be the biggest global health threat of the $21^{\text {st }}$ century. Healthcare is not only adversely impacted by but also a significant contributor to global warming and environmental degradation. Healthcare provision produces $4.6 \%$ of the total national greenhouse gas emissions in Canada, while healthcare waste has increased unabated in recent years, largely because of increased use of disposable medical supplies. Operating rooms are highly energy-intensive and produce up to $33 \%$ of total hospital waste. Increasingly, attention in healthcare is being focused on environmental sustainability by exploring evidence-based approaches to more sustainable delivery of healthcare. Key to environmental sustainability research is the life-cycle assessment methodology, which measures the cradle-tograve impact of products on various environmental outcomes and empowers purchasing departments to make environmentally conscious decisions. By using the "reduce,
\end{abstract}

M.-A. Petre, MD, FRCPC ( $\square)$

Department of Anesthesiology, Montreal Children's Hospital, McGill University, Montreal, QC, Canada

e-mail: maria.petre@mcgill.ca

S. Malherbe, MBChB, FRCPC, MMed

Department of Anesthesiology, Pharmacology \& Therapeutics, British Columbia Children's Hospital, University of British

Columbia, Vancouver, BC, Canada reuse, recycle" hierarchy of waste reduction, several easily implementable evidence-based strategies are proposed to reduce the environmental footprint of everyday anesthesia practice. These recommendations focus on informed decisions on volatile anesthetic use, reduced drug waste, limited use of single-use devices, and meticulous waste segregation and recycling strategies.

Conclusions Anesthesiologists have a unique opportunity to be champions of environmental sustainability through evidence-based practices, while simultaneously reaping significant synergistic health, cost, and quality co-benefits.

\section{Objectives of this continuing professional development (CPD) module}

After reading this module, the reader should be able to:

1. Define environmental sustainability as it applies to anesthesia practice.

2. Discuss the role of life-cycle assessment in identifying environmentally sustainable options for commonly used anesthesia equipment.

3. Outline the environmental impact of commonly used anesthetic agents and methods of mitigating these effects.

4. Determine the role of recycling in reducing the environmental impact of modern anesthetic practice. 


\section{The impact of healthcare, surgery, and anesthesia}

The Lancet Commission on Climate Change has indicated that climate change and environmental degradation pose significant risks to public health. ${ }^{1,2}$ The provision of healthcare is a significant contributor to global warming, with healthcare-related activities producing $4.6 \%$ and $10 \%$ of the total national greenhouse gas (GHG) emissions in Canada and the US, respectively. ${ }^{3,4}$ As other industries have made efforts to reduce their emissions, healthcare's proportional impact continues to grow. In addition to GHG emissions, healthcare also contributes significantly to acid rain production, smog formation, criteria air pollutants, stratospheric ozone depletion, and air toxins. ${ }^{3}$ Indeed, the environmental impact of healthcare-related activities may translate to an estimated 23,000 and 405,000 disabilityadjusted life years lost annually in Canada and the US, respectively. ${ }^{3,4}$ These figures are equivalent to the number of annual deaths due to medical errors identified in the Institute of Medicine report "To Err is Human", the result of which was the topic of national discourse and which led to the inception of the patient safety movement. ${ }^{3}$ In addition to health imperatives driving changes in practice, the required urgency for such changes is further underscored by reports from the Intergovernmental Panel on Climate Change, which have indicated that immediate and substantive actions are required to avert the most significant effects of climate change. ${ }^{5}$

Within healthcare, hospitals make disproportionately large contributions to emissions and resource utilization, with operating rooms (ORs) being highly energy-intensive. A wide variability in per-case emissions across institutions indicates that significant gains can be made towards greening the ORs. ${ }^{6}$ Anesthesiologists have expressed a strong interest in the environmental impact of their practice $^{7}$ and will be instrumental in spearheading the application of evidence-based practices to make surgical services and healthcare more environmentally sustainable. ${ }^{6,8}$ The current article aims to highlight various strategies that can be applied by Canadian anesthesiologists to improve the environmental sustainability of their practice.

\section{Sustainability}

Sustainability in healthcare has been defined as the "idea that healthcare services should be planned, financed, and delivered in ways that allow them to meet the needs of future generations as well as today's population". ${ }^{9}$ While financial sustainability is well understood, increasing attention must focus on environmental sustainability. This entails not only reducing the environmental impact of healthcare-related activities, but also ensuring that current healthcare systems are adaptable to climate-related changes, including increased disease burdens and scarcity of natural resources such as water and fuels.

While environmental sustainability may be viewed as necessitating a trade-off between fiscal sustainability and patient safety, it becomes evident that this is often not the case when a system-wide view is taken. Indeed, by finding efficiencies in healthcare using new technologies, disease prevention strategies, and evidence-based approaches, we could reap not only environmental benefits but also significant synergistic health, financial, and quality cobenefits. $^{9}$

\section{Life-cycle assessment (LCA)}

A staple of environmental sustainability studies is the LCA methodology, which aims to measure the cradle-to-grave impact of a product on various environmental outcomes. The methodology entails the summation of the raw resources, energy, emissions, and waste resulting from the production, use, reuse and ultimate disposal of a product (Figure). ${ }^{10,11}$ Various endpoints can be examined in the analysis including GHG emissions, smog formation, ozone depletion, and the pollution of the environment with carcinogenic and non-carcinogenic toxins. Tabulating the environmental effects of a product across its life-cycle allows comparison with alternative products, which empowers purchasing departments to make environmentally conscious decisions. It can also highlight those portions of a product's life-cycle which can be altered to decrease its overall environmental impact. This methodology has been applied to highlight the life-cycle impact of different approaches to the same surgery, ${ }^{8}$ the impact of various modalities of anesthesia, ${ }^{12}$ as well as the impact of reusable compared with single-use products. ${ }^{13}$

An additional benefit of analyzing the life-cycle of a product is that it allows a more comprehensive calculation of the overall cost to the healthcare system, which expends money not only in the purchase of a product but also in its disposal and potential cleaning, sterilization, and repackaging for multi-use products. Such calculations known as life-cycle costing (LCC) have bolstered the argument in favour of strategies such as pre-filled syringes $^{14}$ and reusable laryngeal mask airways (LMAs) ${ }^{13}$ and laryngoscopes,${ }^{15}$ by showing that these are not only more environmentally sustainable, but also more cost-efficient for the healthcare institution as a whole.

While LCCs and LCAs are powerful methods for helping purchasing departments make environmentally sound choices, they are product- and context-specific. ${ }^{13}$ For example, if a large proportion of a product's 
environmental footprint depends on the use of electricity, the overall results of an LCA will depend on whether that electricity is consumed in a country/province in which electricity is sourced from coal, nuclear, or renewable sources. Furthermore, LCAs may rely on estimates of proprietary manufacturing processes that companies may not readily share with researchers. Lastly, LCAs can be expensive and require significant expertise to conduct. Thus, while it may not be practical to conduct an LCA for each product comparison, data could be adapted from previously published LCAs to the local context to inform purchasing decisions. ${ }^{13}$

\section{General strategies for improved environmental sustainability in healthcare}

A recent report from the UK has indicated that $65 \%$ of the National Health Service's total carbon emission profile was related to procurement (through the subsumed carbon footprints of the purchased pharmaceuticals, medical equipment, and food services), $19 \%$ to energy use, and $16 \%$ to travel of patients and staff. ${ }^{9}$ While many strategies may tackle the environmental footprint in each of these sectors, ${ }^{16}$ a subset of evidence-based strategies is discussed below.

With procurement representing two thirds of healthcare institutions' total carbon emission profiles, ${ }^{9}$ significant carbon footprint reductions may be achieved though evidence-based purchasing decisions. Although physicians are not often directly involved in these decisions, it is the authors' opinion that sustained discussions with pharmaceutical and medical equipment representatives and purchasing directors may signal our profession's interest in a product's LCA and environmental impact and not just its efficacy and price. This may lead healthcare companies to begin producing and publishing such assessments and optimizing their production processes to become more competitive in their environmental footprint. Pharmaceuticals are among the most carbon-intensive purchases made by healthcare institutions and often have a larger environmental footprint than other common chemicals on a per kilogram basis, ${ }^{9,17}$ indicating that drugs' lifecycles may be particularly amenable to optimization.

Energy use is the second major contributor to healthcare's carbon footprint, through the provision of heating, ventilation, air conditioning, sterilization, laundry, lighting, equipment, and food preparation. ${ }^{18}$ In addition to ensuring that new equipment purchases and hospital building designs use the most energy-efficient technologies and designs, programs such as nighttime equipment shut-off and turning off ventilation and lights to rooms which are not being used may decrease both costs and environmental impact without significant investments in new infrastructure.

The third major category of activity contributing to healthcare institutions' carbon emissions is patient and worker travel. Novel approaches such as the implementation of telemedicine, ${ }^{19,20}$ used in conjunction with efficiencies gained from province- or nation-wide electronic medical records, ${ }^{21}$ may minimize the environmental and economic impact of patient travel for preoperative visits and required testing. Further decreases in car journeys could be achieved by improvements in more environmentally friendly modalities, such as the hospital's public transit network and bicycle facilities, ${ }^{22}$ which may improve the hospital's environmental footprint, as well as the health of the facility's patients and workforce.

Many of these initiatives are outside the scope of a single department and it is difficult for individual services to take ownership of such projects. It is here that hospitalwide "green teams" with representation from perioperative services, including nursing, surgeons, anesthesiologists, custodial staff, infection control, and purchasing
Figure Life-cycle assessment methodology aims to summate raw resources, energy, emissions, and wastes resulting from the production, use, reuse, and ultimate disposal of a productLa méthodologie d'analyse du cycle de vie a pour objectif de faire la somme des ressources brutes, de l'énergie, des émissions et des déchets résultant de la production, de l'utilisation, de la réutilisation et de l'élimination finale d'un produit

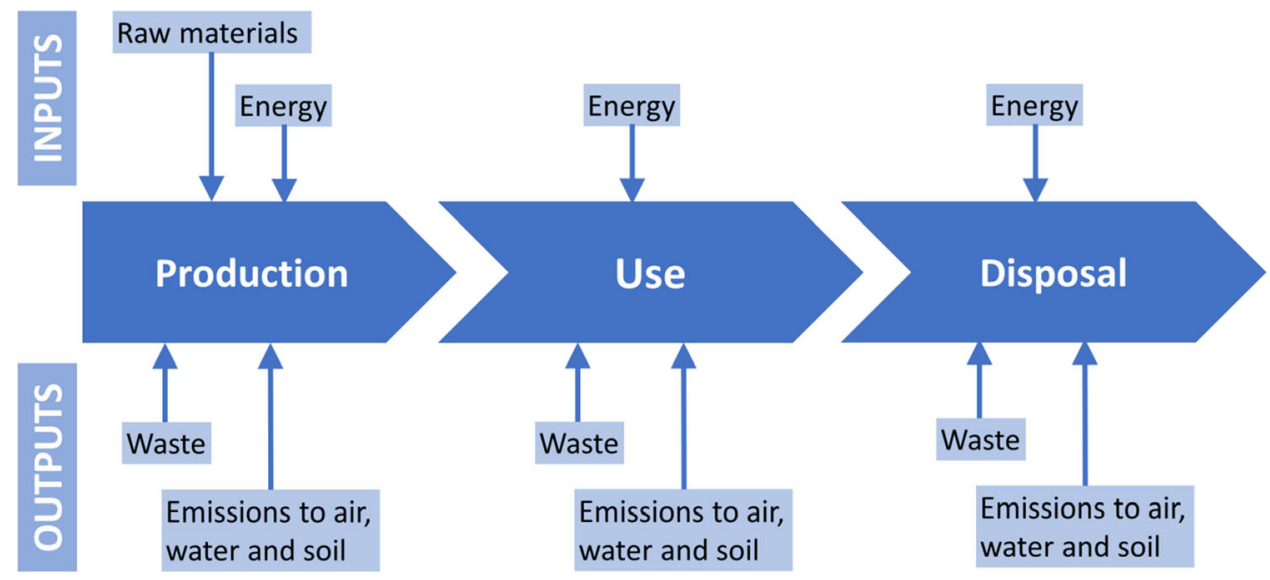


representatives, have been particularly helpful. Such teams can identify opportunities for improving environmental sustainability, raising awareness, educating other staff, and spearheading multilateral initiatives to minimize the negative environmental impacts of healthcare institutions. ${ }^{23,24}$

The remainder of the article will use the "Reduce, reuse, recycle" hierarchy of waste reduction to propose easily implementable evidence-based methods to specifically reduce the environmental footprint of anesthesia practice (Table 1).

\section{Reduce}

Inhaled anesthetic agents and nitrous oxide $\left(\mathrm{N}_{2} \mathrm{O}\right)$

Once emitted into the atmosphere in the form of waste gas streams, inhaled anesthetic agents and $\mathrm{N}_{2} \mathrm{O}$ act as strong greenhouse gases $(\mathrm{GHG})$ that persist in the atmosphere for years to decades. ${ }^{25,26} \mathrm{~A}$ measure of their heat trapping potency is the global warming potential (GWP), which is commonly expressed over either a 20-year (GWP20) or a 100-year (GWP100) time horizon. ${ }^{25,26}$ The GWP represents the relative increase in the global warming for a unit of gas released into the atmosphere in comparison to the same unit of carbon dioxide $\left(\mathrm{CO}_{2}\right)$. Desflurane has the highest GWP, being thousands of times more potent than $\mathrm{CO}_{2}$. Sevoflurane has the lowest GWP, but is still hundreds of times more potent than $\mathrm{CO}_{2}$. These can easily be converted to 20-year carbon dioxide equivalents (CDE20), taking into account the differential mean alveolar concentrations used in clinical practice, to allow comparison with common activities such as driving a vehicle (Table 2) ${ }^{25,26}$ For a full explanation of GWPs and CDEs, see Ryan et al. and Andersen et al. ${ }^{25,26}$ Given that emissions of inhaled anesthetic agents are among the largest sources of GHG emissions from ORs, ${ }^{6}$ managing inhalational anesthetic administration represents the biggest opportunity for anesthesia providers to improve their impact on environmental sustainability.

Several strategies have been suggested to reduce the environmental impact of general anesthesia, ${ }^{27}$ the most important being the choice of agent. Total intravenous anesthesia (TIVA) with propofol has a GHG impact several magnitudes smaller than that of inhaled agents as shown in a comparative cradle-to-grave LCA. $^{12}$ A potential disadvantage of TIVA, however, is that large amounts of unused propofol are wasted on a routine basis, and unmetabolized propofol has detrimental environmental effects primarily because of its environmental persistence and aquatic ecotoxicity. ${ }^{28}$ Other techniques which may hold promise for reducing the environmental impact of anesthesiology is the use of neuraxial or regional anesthesia. ${ }^{29}$ Indeed, such techniques may substantially eliminate emissions of volatile agents while relying on local anesthetics and sedative agents which may have similar environmental toxicity profiles as propofol but may be used in much lower quantities. ${ }^{30}$ Nevertheless, to date, no LCAs have been conducted to elucidate the relative environmental footprint of regional anesthesia in comparison with TIVA and inhalational anesthetics. In cases in which inhalational agents are clinically preferred, forgoing the use of desflurane and $\mathrm{N}_{2} \mathrm{O}$ in favour of sevoflurane or isoflurane with air-based fresh gas flows (FGF) can reduce GHG emission per minimum alveolar concentration hour by as much as 20 times. $^{12}$ Indeed, systematically switching from desflurane to sevoflurane with low FGF in several Vancouver hospitals resulted in a $66 \%$ reduction in GHG emissions over a five-year period, equivalent to eliminating the annual emissions produced by 1,700 personal vehicles driving an average of $22,000 \mathrm{~km} /$ year. $^{31}$

A second strategy focuses on minimizing FGF to reduce emissions of inhalational agents during each phase of an anesthetic. ${ }^{32}$ If an inhalational induction is chosen, as is often the case in pediatric anesthesia, traditional teaching is to mask-ventilate the patient using a high FGF and to turn off the vaporizer when the mask is removed for intubation. Nevertheless, the better solution is to turn off the FGF and leave the vaporiser on during intubation, thereby preserving the concentration of gases in the circuit. ${ }^{32}$ Alternatively, when TIVA is planned for the maintenance phase, even in pediatrics, intravenous induction may be both clinically and environmentally preferable to inhalational induction. ${ }^{33}$ If volatile maintenance is planned following intravenous induction of anesthesia, a higher FGF is required during the initial phase of a volatile maintenance to compensate for a higher uptake of inhalational agent from the patient. It is however possible to use lower flows during this phase by utilizing the concept of "overpressure." The relatively stable gas concentrations during the maintenance phase provide an ideal opportunity for using closed-circuit or low-FGF anesthesia, closely approximating flows that meet the patient's oxygen consumption, which may be further facilitated by modern anesthesia machines. During emergence from anesthesia, waste will be reduced if the FGF is kept low until the vaporizer is turned off. ${ }^{32} \mathrm{~A}$ potential disadvantage of low FGFs is the increased requirement for a $\mathrm{CO}_{2}$ absorbent whose own concomitant footprint remains to be elucidated in an LCA study; however, this is unlikely to offset the benefits of reducing inhalational agents and $\mathrm{N}_{2} \mathrm{O}$ emissions.

Even when low FGFs are used, substantial amounts of scavenged gases are released into the atmosphere. These 
Table 1 Summary of strategies that can be employed to improve the environmental sustainability of anesthesia practice

\section{Strategies}

\section{General strategies (often requiring multi-disciplinary involvement)}

Promote and participate in developing LCA and life-cycle costing studies for commonly used products to inform environmentally conscious purchasing practices

Apply sustained pressure on pharmaceutical and medical equipment sales representatives to produce LCA data for their products to present to purchasing managers

Purchase energy-efficient equipment

Shut-off ventilation, lights, and equipment at nighttime

Implement telemedicine technology for preoperative consults, meetings, and conferences

Implement electronic medical records to eliminate unnecessary tests and trips to hospitals and testing centres

Use public transit, walking, and biking for work travel

Assemble and participate in hospital and OR green teams

Participate in special interest groups or environmental sustainability subsections of professional organizations (such as the Canadian Anesthesiologists' Society Section for Environmental Sustainability) to foster local adoption of best practices and national and international collaboration

Participate in practical and didactic teaching of trainees on environmental sustainability topics

Avenues for further research:

Determine the long-term environmental impact of using the perioperative period as an opportunity for health promotion and disease prevention (i.e., by broaching preoperative discussions regarding weight-loss and smoking cessation)

\section{Reduce}

Reduce use of anesthetics gases with large carbon footprints by:

Using TIVA instead of inhalational anesthesia

Using regional anesthesia whenever possible

Considering the use of isoflurane or sevoflurane with air-based fresh gas flow instead of desflurane and $\mathrm{N}_{2} \mathrm{O}$-based fresh gas flow

Implementing gas scavenging technology

Avoid drug wastage by refraining from pre-emptively drawing up emergency paralytic and vasoactive drugs

Work with pharmacists to develop pre-filled syringe programs for commonly used drugs

Avenues for further research:

LCA of regional anesthesia in comparison with TIVA and inhalational anesthesia

Use of surgical suction for airway toileting at extubation instead of contaminating anesthetic suction whenever possible

Reduction of packaging and instructional materials for pre-packaged kits

\section{Reuse}

Reusable devices are often more environmentally sustainable compared with their single-use counterparts including reusable SGAs, textiles, laryngoscope handles and blades, and sharps containers

Consider reusing breathing circuits with an appropriate filter at the circuit $\mathrm{Y}$

Consider engaging in programs for reprocessing single-use devices

Work closely with infection control teams to ensure safety of patients in the reuse process

Avenues for further research:

Results of LCAs are context specific, so where hospital profile differs significantly from conditions of previous LCAs, consider reconfirming the results in your hospital's context

LCAs required for anesthesia equipment, such as processed electroencephalogram monitors, reusable and disposable versions of glidescope blades, or reusable circulating water blankets, compared with single-use air warming blankets

\section{Recycle}

Consider appropriate segregation of biomedical and general waste

Encourage participation in recycling programs for plastic, glass vials, and paper/cardboard

$\mathrm{LCA}=$ life-cycle assessment; SGA = supraglottic airway; $\mathrm{N}_{2} \mathrm{O}=$ nitrous oxide; $\mathrm{OR}=$ operating room; TIVA = total intravenous anesthesia .

emissions are the focus of a third strategy. Gas capture technology relies on silica zeolite filters to adsorb and trap anesthetic gases from the scavenging system prior to their exhaust to the atmosphere, with an efficiency of $\sim 75 \%$. $^{34}$
The gas is trapped in canisters and can then be retrieved and purified at a company facility. The ultimate goal of recycling and re-selling the retrieved volatile agents is currently awaiting Health Canada approval. ${ }^{35}$ 
Table 2 Comparison of atmospheric lifetimes, global warming potential, $\mathrm{CO}_{2}$ equivalents, driving equivalents, density, and molecular weight of inhalational agents and $\mathrm{N}_{2} \mathrm{O}$

\begin{tabular}{llrlllll}
\hline & $\begin{array}{l}\text { Atmospheric life- } \\
\text { time }(\mathrm{yr}) \dagger\end{array}$ & $\begin{array}{l}\text { GWP- } \\
20 \dagger\end{array}$ & $\begin{array}{l}\text { Amount of gas used } \\
\left(\mathrm{g} \cdot \mathrm{hr}^{-1}\right)\end{array}$ & $\begin{array}{l}\text { Hourly } \\
\text { CDE20 } \ddagger(\mathrm{g})\end{array}$ & $\begin{array}{l}\text { Hourly driving } \\
\text { equivalents }(\mathrm{km}) ¥\end{array}$ & $\begin{array}{l}\text { Density } \\
\left(\mathrm{g} \cdot \mathrm{m}^{-3}\right)\end{array}$ & $\begin{array}{l}\text { Molar mass } \\
\left(\mathrm{g} \cdot \mathrm{mol}^{-1}\right)\end{array}$ \\
\hline Sevoflurane & 1.1 & 440 & $10^{*}$ & $4,400^{*}$ & $19.1^{*}$ & 1.52 & 200 \\
Isoflurane & 3.2 & 1,800 & $5.5^{*}$ & $9,900^{*}$ & $43^{*}$ & 1.5 & 184.5 \\
Desflurane & 14 & 6,810 & $25.2^{*}$ & $171,612^{*}$ & $746.1^{*}$ & 1.47 & 168 \\
$\mathrm{~N}_{2} \mathrm{O}$ & 114 & 289 & $55^{* *}$ & $15,895^{* *}$ & $69^{* *}$ & 1.98 \\
\hline
\end{tabular}

$\mathrm{CDE} 20=20$-year carbon dioxide equivalent; $\mathrm{CO}_{2}=$ carbon dioxide; GWP20 = 20-year global warming potential; $\mathrm{N}_{2} \mathrm{O}=$ nitrous oxide . $\dagger$ Numbers obtained from Andersen et al. ${ }^{25}$

*Based on 1 minimum alveolar concentration hour use of $1 \mathrm{~L} \cdot \mathrm{min}^{-1}$ fresh gas flow. Note that the values are directly and linearly proportional to the fresh gas flow.

**Based on $500 \mathrm{~mL} \cdot \mathrm{min}^{-1}$ fresh gas flow

\$CDE20 is calculated as mass of agent $(\mathrm{g}) \mathrm{x}$ GWP-20

$¥$ Hourly driving equivalents based on $10 \mathrm{~km} \cdot \mathrm{L}^{-1}$ fuel consumption and burning $1 \mathrm{~L}$ of gasoline producing $2.3 \mathrm{~kg}$ of $\mathrm{CO}_{2}$. Calculated from volume of anesthetic gas used as follows: Driving equivalents $=$ volume of gas $(\mathrm{mL}) \times$ density $\left(\mathrm{g} \cdot \mathrm{mL}^{-1}\right) \times \mathrm{GWP} 20 \mathrm{x}(\mathrm{km}$ driven/L of gasoline $) /$ (mass of $\mathrm{CO}_{2}$ produced / $\mathrm{L}$ gasoline).

Unfortunately, this capture technology does not adsorb $\mathrm{N}_{2} \mathrm{O}{ }^{36}$

\section{Drug waste}

An estimated $25-30 \%$ of the total anesthesia drug budget is routinely wasted. $^{37}$ Thus, more efficient use of pharmaceuticals can minimize the environmental impact of such waste while accruing significant budgetary benefits. Propofol is the most widely dispensed and wasted drug with as much as $32-49 \%$ being wasted. ${ }^{28,37}$ Similarly, anesthesia providers often routinely prepare cardiac resuscitative drugs (such as ephedrine, atropine, and phenylephrine) and paralytic agents, which are unused up to $50 \%$ of the time. ${ }^{14,28,38}$ Given that anesthesiologists are proficient at drawing up unprepared drugs, one less wasteful approach is to keep emergency ampoules and syringes on hand so that they can be easily prepared when needed. A second approach has been for hospital pharmacies to prepare pre-filled syringes of commonly used anesthesia drugs, which reduces drug waste and leads to significant savings. ${ }^{39}$

The importance of drug wastage is becoming increasingly clear as we elucidate the chronic toxicity and environmental effects of pharmaceuticals in the water supply. For example, unmetabolized propofol poses a particular environmental hazard since it does not degrade, is very toxic to aquatic organisms, is highly mobile in soil, and accumulates in fat. ${ }^{28}$ Because of this, adequate disposal of propofol requires incineration in accordance with manufacturer and pharmaceutical waste regulation. ${ }^{28}$
Anesthesia providers should remain mindful of the drugs they draw up and cognizant of the environmental and financial implications of the avoidable waste. ${ }^{35}$

Other opportunities for waste reduction

Several other opportunities for waste reduction can be readily identified and require further research. For example, it is our opinion that cooperating with regulators, manufacturers, and suppliers may help reduce the amount of unnecessary materials, packaging, and instructional inserts that are often found in prepared bundles such as central line, spinal, and epidural kits. Another under-appreciated source of anesthesia waste is anesthesia suction, which could be eliminated by using surgical suction with a new Yankauer tip to suction the patient's airway at extubation.

\section{Reuse}

Concerns regarding infection risk have resulted in the widespread move to single-use medical devices, which is largely responsible for the increase in healthcare waste in recent years. While this is an important patient safety consideration, these concerns must be balanced against the pollution-related public health impacts of increased healthcare waste production. ${ }^{40}$ Thus, LCA methodology has recently been used to quantify and compare the footprint of reusable and single-use alternatives of commonly used anesthesia products. 
Supraglottic airways

The reusable and single-use versions of supraglottic airways such as the LMA $^{\circledR}$ (Teleflex Medical Canada Inc., Markham, ON, Canada) are equivalent in their clinical effectiveness and ease-of-use. Eckelman et al. performed an LCA comparing 40 uses of a single reusable Classic ${ }^{\mathrm{TM}}$ LMA with 40 one-time uses of single disposable Unique ${ }^{\mathrm{TM}}$ LMAs across several categories of environmental and human health impacts. ${ }^{13}$ Despite requiring repeated cleaning, packaging, and re-sterilization, the environmental impact strongly favoured the reusable devices, which also had a lower per-use cost.

\section{Reusable textiles}

Reusable gowns and drapes show substantial sustainability benefits over disposable products in resource energy use, water use, carbon footprint, volatile organics, and solid waste production, while cost, protection, and comfort are similar. ${ }^{41,42}$

\section{Breathing circuits}

The reuse of anesthesia breathing circuits is a controversial topic. Many anesthesia departments reuse single-use circuits with a new filter at the circuit $\mathrm{Y}$ for each case, whereas others insist on a new circuit for each patient. Although Canadian institutions have not offered guidance on this issue, the German Anesthesiology Society supports the use of anesthesia circuits for up to seven days, ${ }^{43}$ while the Association of Anesthetists of Great Britain and Ireland supports the use of circuits for an entire day, provided an appropriate filter with a retention efficiency for air-borne particles of $>99 \%$ is changed between patients. ${ }^{44}$ Circuits are only changed between patients and discarded if visibly contaminated or used for highly infectious cases, e.g., tuberculosis. Indeed, disposable bacterial filters prevent the transmission of air-borne bacteria and protect the breathing circuit from bacterial contamination for up to one week. ${ }^{45,46}$ Thus, while LCAs remain to be conducted to compare the use of high-efficiency filters, anesthesiologists are urged to work with their local infection control committee and reuse anesthesia circuits.

\section{Other products}

Life-cycle assessments have indicated that reusable laryngoscope handles and blades, ${ }^{15}$ sharps containers, ${ }^{47}$ but not central line kits, ${ }^{48}$ have decreased environmental impact compared with their single-use alternatives. Taken in aggregate, these studies indicate that while reusable options seem to be preferable, such comparisons are product- and context-specific ${ }^{49}$ and LCA comparisons must be conducted when such data are not available, such as in the comparison of reusable and disposable videolaryngoscope blades or reusable circulating water blankets with single-use air-warming blankets.

Reprocessing single-use devices (SUDs)

The "single-use" label on medical devices is often chosen at the manufacturer's discretion and may be influenced more by creative marketing than good evidence. The reprocessing of many SUDs has become routine in some centres in an effort to reduce costs and improve waste management. ${ }^{50}$ Reprocessing of SUDs can occur within a hospital or by contracted third-party reprocessors, which allows hospitals to "buy back" reprocessed devices at a significant discount. ${ }^{50} \mathrm{~A}$ list of commonly reprocessed SUDs can be found from the Association of Medical Device Reprocessors and includes blood pressure cuffs, tourniquet cuffs, pulse oximetry sensors, and anesthesia masks. $^{50,51}$

\section{Infection risk}

Limited studies on the infection risk associated with reuse of products have indicated that such risk arises from reusing defective complex equipment (e.g., flexible bronchoscopes) or inappropriately applied cleaning policies. ${ }^{52-54}$ When they occur, these incidents of disease transmission can be catastrophic to the patients and families involved. Thus, systematic audits are required to quantify the global- and equipment-specific risk of reprocessing and reuse to balance the potential individual risk to patients and the public health risk of ever-increasing medical waste. ${ }^{40}$

\section{Recycle and segregate}

Operating rooms generate between $20 \%$ and $33 \%$ of total hospital waste, ${ }^{55}$ with anesthesia-related waste representing as much as $25 \%$ of all trash produced during surgery. ${ }^{56}$ Medical waste is typically divided into two categories: biomedical and general waste. Biomedical waste may be contaminated with body fluids and has the potential to cause disease. It is significantly costlier to dispose of and has a greater environmental impact since it needs to be either incinerated or autoclaved before being sent to a landfill.

Expert opinion suggests that biomedical waste should not constitute more than $15 \%$ of an institution's total waste stream. Unfortunately, more than $70 \%$ of general OR waste, which is potentially recyclable, is incorrectly 
Table 3 Potentially recyclable anesthesia waste materials

\begin{tabular}{ll}
\hline Plastics* & Paper \\
\hline Surgical instrument wraps (including blue wrap) & Boxboard \\
Forced-air warming blankets & Paper package inserts \\
Saline and water ampoules and bottles & Rippable paper packaging \\
Uncontaminated intravenous fluid bags and tubing & \\
Oxygen masks and tubing & \\
Suction tubing & \\
Uncontaminated syringes & \\
Hard plastic packaging (procedure equipment trays, ex. central line trays) & \\
\hline
\end{tabular}

*Recyclable plastics include polypropylene, polyethylene, polyurethane, polyvinylchloride. The list of recyclable plastics was obtained from McGain et al. $^{59}$

disposed of as biomedical waste, resulting in increased disposal costs and deleterious effects on the environment. ${ }^{57}$ Wyssusek et al. have shown that after introducing a refined OR waste segregation program, biomedical waste was reduced to $18 \%$ of total OR waste, translating to an $80 \%$ reduction of waste management costs. ${ }^{57}$ One example of such a waste segregation strategy of specific relevance to anesthesia is the use of sharps containers that are autoclaved before disposal at significant financial and environmental costs. The content of sharp containers should be limited to items capable of cutting or puncturing the skin; this would include needles but not the syringes attached to them.

The processing cost for recycling is less than that of solid waste disposal and it is estimated that approximately $60-70 \%$ of general anesthesia waste can be recycled. ${ }^{57,58}$ This is because of the common arrangement that hospitals must pay waste management companies to have wastes removed, but can sell their recycling to recycling companies. Thus, meticulous recycling can result in substantial savings, with further decreases in the expense of solid waste potentially resulting from negotiated rebates from industrial recyclers. Nevertheless, despite the environmental and financial benefits of recycling and a high interest among anesthesiologists to recycle, recent surveys indicate that less than a third of Canadian anesthesiologists recycle at work. ${ }^{7}$ Barriers such as lack of support from hospital leadership and inadequate information and education may play a role in this gap. ${ }^{7}$ A further major barrier to fully capture recyclable material from the OR is concern from recycling facilities regarding infectious contamination of the material and exposure of recycling facility workers to bodily fluids. ${ }^{37}$ One method to overcome this concern is to collect the recyclable components of packaging during the case set-up phase, before the patient enters the OR. ${ }^{35}$ Examples of potentially recyclable anesthesia-related materials are found in Table 3; however, the specific subset of materials that can be recycled vary considerably not only between institutions but also between countries. ${ }^{59,60}$ Readers are encouraged to contact their local recycling representative for further guidance.

\section{Future steps}

Future endeavours should focus on unifying the Canadian anesthesia community in aiming to decrease the environmental footprint of our speciality. Participation in special interest groups or subsections of national and international professional organizations (such as the Canadian Anesthesiologists' Society Section for Environmental Sustainability) may facilitate collaborative data generation and research, guideline development, and knowledge dissemination efforts. These organizations could also play an important role in political advocacy campaigns, helping to make environmental sustainability a quality metric in hospital accreditation. In addition, clinicians should embrace an educational role in shaping the priorities of future generations of physicians, either by incorporating information about environmental sustainability in their didactic teaching or by modelling environmentally sustainable practice. ${ }^{61}$

\section{Conclusion}

Healthcare is not only adversely impacted by but also a significant contributor to climate change and environmental degradation. Anesthesiologists are in a unique position to champion the environmental sustainability of the healthcare system through evidencebased practices, while simultaneously bolstering its quality and financial sustainability. To continue our mission of providing excellent care to individual patients in the 
coming generations, we must embrace the opportunity to be stewards of the healthcare system entrusted to us.

\section{Clinical scenario}

You are about to conduct an anesthetic for a healthy threeyear-old child scheduled to undergo an inguinal hernia repair. You are considering strategies that can be followed as part of the anesthetic management to decrease the environmental impact of the anesthetic.

\section{Instructions for completing the continuing professional} development (CPD) module:

1. Read the current article and the references indicated in bold.

2. Go to: https://www.cas.ca/en/education/continuingprofessional-development/cpd-modules to access our learning management system, $\log$ in and select the current module (Environmentally sustainable perioperative medicine: simple strategies for anesthetic practice). Your username is your email address in the member directory and your password is your Canadian Anesthesiologists' Society identification number. This module is accredited for three years. You can find the exact accreditation period on the CAS website and in the learning management system.

3. Answer the multiple choice questions regarding the case scenario.

4. Once you have entered all your answers, you will have access to experts' explanations for all the possible choices.

5. Participants may claim up to four hours of CPD under Section 3 of the MOC Program of the Royal College of Physicians and Surgeons of Canada.

\section{La médecine périopératoire durable: quelques stratégies simples pour la pratique de l'anesthésie}

\section{Résumé}

ObjectifCe module de développement professionnel continu a pour objectif de conscientiser les anesthésiologistes quant à l'ampleur du gaspillage et des déchets liés aux soins de santé et leur contribution au réchauffement climatique, ainsi que de proposer des stratégies générales pour améliorer la durabilité environnementale dans la pratique quotidienne de l'anesthésie dans un contexte canadien.

Considérations principales Le réchauffement climatique est considéré comme la plus importante menace en matière de santé mondiale au $\mathrm{XXI}^{\mathrm{e}}$ siècle. D'un côté, les soins de santé sont victimes des impacts négatifs du réchauffement climatique et de la dégradation de l'environnement, mais de l'autre, ils y contribuent également de façon significative. La fourniture de soins de santé produit 4,6\% des émissions nationales totales de gaz à effet de serre au Canada, alors que les déchets médicaux ne cessent d'augmenter depuis quelques années augmentation due en grande partie à l'utilisation accrue de matériels médicaux jetables. Les salles d'opération sont particulièrement énergivores et produisent jusqu'à $33 \%$ des déchets hospitaliers totaux. Dans les soins de santé, l'attention se tourne de plus en plus vers la durabilité en explorant des approches fondées sur des données probantes pour une fourniture plus écologique des soins de santé. La méthodologie d'analyse du cycle de vie est un élément crucial de la recherche en durabilité : cette méthodologie mesure l'impact d'un produit, de sa création à son élimination, sur différents résultats environnementaux. Elle permet aux services d'approvisionnement d'être mieux outillés pour prendre des décisions écoresponsables. En s'appuyant sur la hiérarchie des $3 \mathrm{R}$ « réduire, réutiliser, recycler» pour la réduction des déchets, nous proposons plusieurs stratégies fondées sur des données probantes et faciles à mettre en œuvre afin de réduire l'empreinte environnementale de la pratique quotidienne de l'anesthésie. Ces recommandations mettent l'emphase sur des stratégies concernant divers aspects promouvant une plus grande durabilité, soit : la gestion de l'utilisation des anesthésiques volatils, la réduction du gaspillage médicamenteux, l'utilisation restreinte des dispositifs à usage unique, le tri méticuleux des déchets et les stratégies de recyclage.

Conclusion Les anesthésiologistes ont une occasion unique de devenir des leaders en durabilité grâce à des pratiques fondées sur des données probantes, tout en récoltant d'importants avantages concomitants et synergiques en matière de santé, de coûts et de qualité.

\section{Objectifs de ce module de Développement professionnel continu (DPC):}

Après avoir lu ce module, le lecteur devrait être en mesure de :

1. Définir la durabilité environnementale telle qu'elle s'applique à la pratique de l'anesthésie. 
2. Discuter du rôle de l'analyse du cycle de vie dans l'identification des options durables en ce qui touche au matériel anesthésique fréquemment utilisé.

3. Décrire l'impact environnemental des agents anesthésiques fréquemment utilisés et les méthodes pour en mitiger les effets.

4. Déterminer le rôle du recyclage dans la réduction de l'impact environnemental de la pratique moderne de l'anesthésie.

\section{L'impact des soins de santé, de la chirurgie et de l'anesthésie}

Selon la Commission sur les changements climatiques de The Lancet, les changements climatiques et la dégradation de l'environnement posent d'importants risques pour la santé publique. ${ }^{1,2}$ La fourniture de soins de santé contribue considérablement au réchauffement climatique, les activités associées aux soins de santé produisant $4,6 \%$ et $10 \%$ des émissions nationales totales de gaz à effet de serre (GES) au Canada et aux États-Unis, respectivement. ${ }^{3,4}$ Alors que d'autres secteurs industriels ont déployé des efforts afin de réduire leurs émissions, l'impact proportionnel des soins de santé continue d'augmenter. Outre les émissions de GES, les soins de santé contribuent également de façon importante à la production des pluies acides, à la formation de smog, aux principaux contaminants atmosphériques, à l'appauvrissement de l'ozone stratosphérique, et aux toxines dans l'air. ${ }^{3}$ En fait, on estime que l'impact environnemental des activités liées aux soins de santé pourrait se traduire en une perte annuelle de 23000 à 405000 années de vie corrigées du facteur invalidité au Canada et aux États-Unis, respectivement. ${ }^{3,4}$ Ces chiffres sont équivalents au nombre de décès annuels dus aux erreurs médicales identifiés dans le rapport de l'Institute of Medicine américain intitulé «To Err is Human» («L'erreur est humaine »), qui fut le sujet d'un débat national avant de se conclure par la création d'un mouvement pour la sécurité des patients. ${ }^{3}$ Outre les impératifs sanitaires motivant des modifications de la pratique, l'urgence nécessaire de tels changements est également soulignée par les comptes rendus du Groupe d'experts intergouvernemental sur l'évolution du climat (GIEC), qui indiquent que des gestes immédiats et substantiels sont nécessaires afin d'éviter les effets les plus importants des changements climatiques. ${ }^{5}$

Au sein des soins de santé, les hôpitaux contribuent de façon disproportionnelle aux émissions et à l'utilisation des ressources, les salles d'opération (SOP) étant particulièrement énergivores. L'importante variabilité des émissions d'une institution à l'autre indique qu'il est possible de faire des gains considérables en rendant les SOP plus écologiques. ${ }^{6}$ Les anesthésiologistes ont fait part d'un intérêt marqué pour l'impact environnemental de leur pratique $^{7}$ et joueront un rôle crucial en prenant la tête de la mise en œuvre de pratiques fondées sur des données probantes afin de rendre les services chirurgicaux et les soins de santé plus durables. ${ }^{6,8}$ Le présent article a pour objectif de présenter diverses stratégies qui peuvent être appliquées par les anesthésiologistes canadiens afin de contribuer à une meilleure durabilité de leur pratique.

\section{La durabilité environnementale}

Dans le domaine des soins de santé, la durabilité environnementale a été définie comme "l'idée que les services de santé devraient être planifiés, financés et offerts de façon à leur permettre de répondre aux besoins des générations futures aussi bien qu'à la population d'aujourd'hui ». ${ }^{9}$ Alors que la durabilité financière est bien comprise, il convient de porter une attention croissante à la durabilité environnementale. Cela implique non seulement de réduire l'impact environnemental des activités liées aux soins de santé, mais également de s'assurer que les systèmes de soins de santé actuels puissent s'adapter aux changements provoqués par le climat, notamment à l'augmentation du fardeau de la maladie et aux pénuries de ressources naturelles telles que l'eau et les combustibles.

Alors qu'on pourrait penser que la durabilité environnementale nécessite inévitablement de compromettre la durabilité fiscale et la sécurité des patients, lorsqu'on considère le système dans son ensemble, il est clair que bien souvent il en va autrement. En effet, en décelant des efficiences en soins de santé à l'aide de nouvelles technologies, de stratégies de prévention des maladies et d'approches fondées sur des données probantes, non seulement pourrions-nous en tirer des avantages environnementaux, mais également d'autres avantages synergiques concomitants importants en matière de santé, de finances et de qualité.

\section{L'analyse du cycle de vie}

L'un des fondements des études en durabilité environnementale s'appuie sur la méthodologie d'analyse du cycle de vie (ACV), qui a pour objectif de mesurer l'impact global d'un produit, de sa création à son élimination, sur différentes cibles environnementales. Cette méthodologie implique la sommation des ressources de base, de l'énergie, des émissions et des 
déchets résultant de la production, de l'utilisation et de l'élimination finale d'un produit (voir illustration). ${ }^{10,11}$ Différents critères peuvent être étudiés dans l'analyse, y compris les émissions de GES, la formation de smog, l'appauvrissement de l'ozone et la pollution de l'environnement par des toxines cancérigènes ou non. En représentant sous forme de tableau les effets environnementaux d'un produit tout au long de son cycle de vie, on peut le comparer à ses alternatives, ce qui permet aux services d'approvisionnement de prendre des décisions écoresponsables. Cette méthode permet également de mettre en lumière les parties du cycle de vie d'un produit qui pourraient être améliorées pour réduire son impact environnemental global. Cette méthodologie a été utilisée pour déterminer l'impact du cycle de vie de différentes approches pour une même chirurgie, ${ }^{8}$ l'impact de diverses modalités anesthésiques, ${ }^{12}$ ainsi que l'impact des produits réutilisables $v s$ leurs pendants à usage unique. ${ }^{13}$

Un avantage supplémentaire de l'analyse du cycle de vie d'un produit est qu'elle permet un calcul plus exhaustif du coût global au système de soins de santé, où l'argent est dépensé non seulement pour l'achat d'un produit, mais également pour son élimination et le nettoyage, la stérilisation et le remballage potentiels des produits à usages multiples. Ces calculs, qu'on appelle évaluation du coût du cycle de vie, ont renforcé l'argument en faveur de stratégies telles que les seringues préremplies ${ }^{14}$ et les masques laryngés (LMA) ${ }^{13}$ et laryngoscopes ${ }^{15}$ réutilisables, en démontrant que ces produits sont non seulement plus durables, mais également plus rentables pour l'établissement de soins de santé dans son intégralité.

Alors que les évaluations du coût du cycle de vie et les ACV constituent des méthodes puissantes pour aider les services d'approvisionnement à faire des choix écoresponsables, ces analyses sont spécifiques à un produit et à un contexte. ${ }^{13}$ Par exemple, si une importante proportion de l'empreinte environnementale d'un produit dépend de l'utilisation d'électricité, les résultats globaux d'une ACV dépendront de si l'électricité est consommée dans un pays ou une province où l'électricité provient du charbon, de sources nucléaires ou renouvelables. En outre, les ACV peuvent se baser sur des estimations de processus de fabrication brevetés que les entreprises ne sont pas prêtes à divulguer aux chercheurs. Enfin, les ACV peuvent être coûteuses à réaliser et nécessiter une expertise importante pour être menées à bien. Ainsi, alors qu'il ne serait pas pratique de réaliser une ACV pour chaque comparaison de produits, les données pourraient être adaptées à partir d'ACV précédemment publiées pour mieux répondre au contexte local et informer les décisions d'achat. ${ }^{13}$
Stratégies générales pour une durabilité améliorée en soins de santé

Un compte rendu britannique récent indiquait que $65 \%$ du profil d'émission de carbone total des Services de santé nationaux (NHS) étaient liés à l'approvisionnement (par les empreintes carbone intégrées des produits pharmaceutiques, du matériel médical et des services alimentaires), $19 \%$ à la consommation énergétique, et 16 $\%$ aux déplacements des patients et du personnel. ${ }^{9}$ Bien qu'il existe de nombreuses stratégies pour s'attaquer à l'empreinte environnementale de chacun de ces secteurs, ${ }^{16}$ nous discuterons ci-dessous d'un sous-ensemble de stratégies fondées sur des données probantes.

L'approvisionnement représentant deux tiers des profils d'émissions carbone totales des établissements de soins de santé, ${ }^{9}$ d'importantes réductions des bilans carbone pourraient être observées en prenant des décisions d'achat fondées sur des données probantes. Il est vrai que bien souvent les médecins ne sont pas directement impliqués dans de telles décisions; selon nous, des discussions soutenues avec les représentants pharmaceutiques et de matériel médical ainsi qu'avec les responsables de l'approvisionnement pourraient cependant démontrer l'intérêt de notre profession pour l'ACV et l'impact environnemental d'un produit, et non pas seulement pour son efficacité et son prix. Cela pourrait inciter les compagnies de soins de santé à commencer à générer et publier de telles analyses, puis à optimiser leurs processus de production afin de devenir plus compétitifs en matière d'empreinte environnementale. Les produits pharmaceutiques comptent parmi les achats des établissements de santé à l'empreinte carbone la plus élevée : en effet, leur empreinte environnementale par kilogramme est souvent plus importante que celle d'autres composés chimiques, ${ }^{9,17}$ indiquant que leurs cycles de vie pourraient se prêter particulièrement bien à une optimisation.

La consommation énergétique est la deuxième composante majeure de l'empreinte carbone des soins de santé, en raison des besoins élevés en matière de chauffage, de ventilation, de climatisation, de stérilisation, de lessive, d'éclairage, de matériel et de préparation de nourriture. ${ }^{18}$ Les programmes visant à garantir que les achats de nouveau matériel et les projets de bâtiments hospitaliers utilisent les technologies et les designs les plus écoénergétiques qui soient pourraient être complétés par d'autres initiatives telles que la mise hors tension nocturne des équipements, de la ventilation et de l'éclairage des salles non utilisées. Ces initiatives permettraient de réduire tant les coûts que l'impact environnemental sans avoir à investir de façon significative dans de nouvelles infrastructures. 
Tableau 1 Résumé des stratégies qui peuvent être utilisées pour améliorer la durabilité environnementale de la pratique de l'anesthésie

\section{Stratégies}

\section{Stratégies générales (nécessitant souvent une implication multidisciplinaire)}

Faire la promotion et participer au développement d'études d'ACV et d'évaluation du coût du cycle de vie pour les produits fréquemment utilisés afin d'informer des pratiques d'achat écoresponsables

Faire pression sur les représentants commerciaux des produits pharmaceutiques et médicaux afin de générer des données d'ACV pour leurs produits à présenter aux responsables des achats

Faire l'acquisition d'équipements écoénergétiques

Mettre hors tension la ventilation, l'éclairage et les équipements pendant la nuit

Implanter des technologies de télémédecine pour les consultations préopératoires, les réunions et les conférences

Implanter des dossiers médicaux informatisés afin d'éliminer les tests et les déplacements inutiles vers les hôpitaux et les laboratoires d'analyse Utiliser les transports publics, la marche et le vélo pour se rendre au travail

Créer et participer à des équipes vertes dans l'hôpital et la SOP

Participer à des groupes d'intérêt ou aux sous-sections dédiées à la durabilité environnementale dans les organismes professionnels (tels que la Section pour la durabilité environnementale de la Société canadienne des anesthésiologistes) afin de promouvoir l'adoption locale des meilleures pratiques et la collaboration nationale et internationale

Participer à l'enseignement pratique et didactique des étudiants à propos de thèmes liés à la durabilité environnementale

Pistes de recherche future :

Déterminer l'impact environnemental à long terme de l'utilisation de la période périopératoire comme occasion pour promouvoir la santé et prévenir les maladies (par ex., en amorçant des discussions préopératoires sur la perte de poids et à l'arrêt du tabagisme)

\section{Réduire}

Réduire l'utilisation des gaz anesthésiques ayant une importante empreinte carbone en :

Privilégiant la TIVA plutôt que l'anesthésie par inhalation

Utilisant l'anesthésie régionale lorsque possible

Envisageant d'utiliser de l'isoflurane ou du sévoflurane avec un débit d'air frais d'air/ $\mathrm{O}_{2}$ plutôt que du desflurane ou un débit d'air frais avec du $\mathrm{N}_{2} \mathrm{O}$

Mettre en place des technologies de captage des gaz

Éviter le gaspillage médicamenteux en ne préparant pas à l'avance les médicaments paralytiques et vasopresseurs d'urgence

Travailler de concert avec les pharmaciens afin de mettre au point des programmes de seringues préremplies pour les médicaments fréquemment utilisés

Pistes de recherche future :

ACV de l'anesthésie régionale par rapport à la TIVA et à l'anesthésie par inhalation

Utilisation de la succion chirurgicale pour l'aspiration des voies aériennes lors de l'extubation au lieu de contaminer la succion anesthésique lorsque possible

Réduction des emballages et des matériaux didactiques dans les trousses préemballées

\section{Réutiliser}

Les dispositifs réutilisables sont souvent plus durables que leurs pendants à usage unique, y compris les dispositifs supraglottiques, les textiles, les manches et lames de laryngoscope et les contenants à objets tranchants

Envisager de réutiliser les circuits respiratoires avec un filtre approprié au raccord en $\mathrm{Y}$

Envisager de participer à des programmes de retraitement des dispositifs à usage unique

Travailler étroitement avec des équipes de prévention des infections afin de garantir la sécurité des patients dans le processus de réutilisation

Pistes de recherche future :

Les résultats des ACV sont spécifiques au contexte; dès lors, lorsque le profil de l'hôpital est très différent des conditions dans les ACV précédentes, il faut envisager de reconfirmer les résultats dans le contexte de votre institution

Les ACV requis pour les équipements d'anesthésie, tels que les moniteurs d'électroencéphalogramme transformés, les versions réutilisables et jetables des lames de vidéolaryngoscope, ou les couvertures avec circulation d'eau réutilisables, par rapport aux matelas chauffants à air à utilisation unique

\section{Recycler}

Envisager le tri approprié des déchets biomédicaux et généraux

Encourager la participation aux programmes de recyclage pour le plastique, les contenants en verre et le papier/carton

$\mathrm{ACV}=$ analyse du cycle de vie; $\mathrm{N}_{2} \mathrm{O}=$ protoxyde d'azote; $\mathrm{SOP}=$ salle d'opération; TIVA = anesthésie intraveineuse totale. 
Tableau 2 Comparaison des durées de vie atmosphériques, du potentiel de réchauffement planétaire, des équivalents $\mathrm{CO}_{2}$, des équivalents de trajets automobiles, de la densité et du poids moléculaire des agents volatils et du $\mathrm{N}_{2} \mathrm{O}$

\begin{tabular}{llrlllrr}
\hline & $\begin{array}{l}\text { Durée de vie } \\
\text { atmosphérique (an) } \dagger\end{array}$ & $\begin{array}{l}\text { PRP- } \\
20 \dagger\end{array}$ & $\begin{array}{l}\text { Quantité de gaz } \\
\text { utilisée }\left(\mathrm{g} \cdot \mathrm{h}^{-1}\right)\end{array}$ & $\begin{array}{l}\text { Éq. CO2- } \\
20 \ddagger(\mathrm{g})\end{array}$ & $\begin{array}{l}\text { Équivalents de conduite } \\
\text { horaire }(\mathrm{km}) ¥\end{array}$ & $\begin{array}{l}\text { Densité } \\
\left(\mathrm{g} \cdot \mathrm{m}^{-3}\right)\end{array}$ & $\begin{array}{l}\text { Masse molaire } \\
\left(\mathrm{g} \cdot \mathrm{mol}^{-1}\right)\end{array}$ \\
\hline Sévoflurane & 1,1 & 440 & $10^{*}$ & $4400^{*}$ & $19,1^{*}$ & 1,52 & 200 \\
Isoflurane & 3,2 & 1800 & $5,5^{*}$ & $9900^{*}$ & $43^{*}$ & 1,5 & 184,5 \\
Desflurane & 14 & 6810 & $25,2^{*}$ & $171612^{*}$ & $746,1^{*}$ & 1,47 & 168 \\
$\mathrm{~N}_{2} \mathrm{O}$ & 114 & 289 & $55^{* *}$ & $15895^{* *}$ & $69^{* *}$ & 1,98 & 44 \\
\hline
\end{tabular}

$\mathrm{CO}_{2}=$ dioxyde de carbone; Éq. CO2-20 = équivalent dioxyde de carbone sur 20 ans; $\mathrm{N}_{2} \mathrm{O}=$ protoxyde d'azote; PRP20 = potentiel de réchauffement planétaire sur 20 ans.

$\dagger$ Chiffres tirés de Andersen et coll. $^{25}$

*Basé sur 1 heure d'utilisation à une concentration alvéolaire minimale (1 MAC) de $1 \mathrm{~L} \cdot \mathrm{min}^{-1}$ de débit de gaz frais. À noter que les valeurs sont directement et linéairement proportionnelles au débit de gaz frais.

**Basé sur $500 \mathrm{~mL} \cdot \mathrm{min}^{-1}$ de débit de gaz frais

†L'éq. CO2-20 est calculé en tant que masse de l'agent (g) x PRP-20

$¥$ Les équivalents horaire de conduite sont basés sur $10 \mathrm{~km} \cdot \mathrm{L}^{-1}$ de consommation de carburant et la combustion de $1 \mathrm{~L}$ d’essence produisant 2,3 $\mathrm{kg}$ de $\mathrm{CO}_{2}$. Calculé en fonction du volume de gaz anesthésique utilisé comme suit : Équivalents de conduite $=$ volume de gaz $(\mathrm{mL}) \mathrm{x}$ densité $\left(\mathrm{g} \cdot \mathrm{mL}^{-1}\right) \times$ PRP20 x (km conduits/L d'essence) / (masse de $\mathrm{CO}_{2}$ produite / L essence).

Le troisième champ d'activité majeur contribuant aux émissions carbone des établissements de santé est lié aux déplacements des patients et des travailleurs. Des approches innovatrices telles que la mise en œuvre de télémédecine, ${ }^{19,20}$ utilisée en conjonction à d'autres efficiences réalisées grâce aux dossiers médicaux informatisés à l'échelle provinciale ou nationale, ${ }^{21}$ pourraient minimiser l'impact environnemental et économique des déplacements des patients pour les consultations préopératoires et les tests requis. On pourrait réduire encore plus les déplacements en voiture en améliorant des modalités plus écologiques, comme par exemple le réseau de transport public de l'hôpital et les installations destinées aux vélos, ${ }^{22}$ ce qui pourrait améliorer l'empreinte écologique de l'hôpital ainsi que la santé des patients et du personnel de l'établissement.

Bon nombre de ces initiatives vont au delà des compétences d'un seul département et il est difficile pour un service seul de se charger de tels projets. C'est là que les «équipes vertes » à l'échelle de l'hôpital deviennent particulièrement utiles: ces équipes peuvent être composées de représentants des services périopératoires, notamment du personnel infirmier, de la chirurgie, de l'anesthésie, du personnel de surveillance, du contrôle des infections ainsi que des achats. De telles équipes peuvent identifier les occasions d'amélioration de la durabilité, lancer des initiatives de conscientisation, éduquer les autres membres $\mathrm{du}$ personnel et mener des initiatives multilatérales afin de minimiser les impacts environnementaux négatifs des établissements de santé. ${ }^{23,24}$

Le reste de l'article s'appuiera sur la hiérarchie des $3 \mathrm{R}$ (« réduire, réutiliser, recycler ») de réduction des déchets pour proposer des méthodes à la fois fondées sur des données probantes et faciles à mettre en œuvre pour réduire l'empreinte écologique spécifique de la pratique de l'anesthésie (Tableau 1).

\section{Réduire}

Agents anesthésiques volatils et protoxyde d'azote $\left(\mathrm{N}_{2} \mathrm{O}\right)$

Une fois libérés dans l'atmosphère sous forme de rejets gazeux, les agents anesthésiques volatils et le $\mathrm{N}_{2} \mathrm{O}$ agissent comme de puissants gaz à effet de serre (GES) et subsistent dans l'atmosphère durant des années, voire des décennies. ${ }^{25,26}$ Le potentiel de réchauffement planétaire (PRP) est une mesure de leur puissance de rétention de la chaleur, fréquemment exprimé sur un horizon temporel de 20 (PRP20) ou 100 (PRP100) ans. ${ }^{25,26}$ Le PRP représente l'augmentation relative du réchauffement climatique pour une unité de gaz libéré dans l'atmosphère par rapport à la même unité de dioxyde de carbone $\left(\mathrm{CO}_{2}\right)$. Le desflurane possède le PRP le plus élevé, étant des milliers de fois plus puissant que le $\mathrm{CO}_{2}$. Le sévoflurane possède le PRP le plus faible, mais il est tout de même des centaines de fois plus puissant que le $\mathrm{CO}_{2}$. Le PRP peut facilement être converti en équivalents dioxyde de carbone sur 20 ans (éq. CO2 20 ), en tenant compte des concentrations de gaz moyennes utilisées dans la pratique clinique, ce qui permet de comparer leur utilisation à des activités courantes comme la conduite d'un véhicule (Tableau 2). ${ }^{25,26}$ Pour une explication complète des PRP et des éq. $\mathrm{CO} 2$, nous vous 
invitons à consulter les travaux de Ryan et coll. et Andersen et coll.. ${ }^{25,26}$ Étant donné que les émissions des agents anesthésiques volatils comptent parmi les sources les plus importantes d'émissions de GES en $\mathrm{SOP}^{6}{ }^{6}$ la gestion de leur administration représente donc une excellente occasion pour les anesthésiologistes d'améliorer leur impact sur la durabilité environnementale.

Plusieurs stratégies ont été proposées pour réduire l'impact environnemental de l'anesthésie générale, ${ }^{27}$ la plus importante touchant au choix de l'agent anesthésique. L'anesthésie intraveineuse totale (TIVA) au propofol a un impact en GES inférieur de plusieurs ordres de grandeur à celui des agents volatils, comme l'a démontré une ACV. ${ }^{12}$ Cependant, un inconvénient potentiel de la TIVA est que d'importantes quantités de propofol non utilisé sont fréquemment gaspillées; en outre, le propofol non métabolisé a des effets environnementaux délétères principalement dus à sa persistance environnementale et à son écotoxicité aquatique. ${ }^{28}$ D'autres techniques potentiellement prometteuses pour réduire l'impact environnemental de l'anesthésiologie comprennent le recours à l'anesthésie neuraxiale ou régionale. ${ }^{29}$ En effet, ces techniques pourraient considérablement éliminer les émissions d'agents volatils en utilisant des anesthésiques locaux et des agents sédatifs ayant des profils de toxicité environnementale certes semblables au propofol, mais à des quantités bien plus faibles. ${ }^{30}$ Toutefois, à ce jour, aucune ACV n'a été réalisée pour comparer l'empreinte environnementale relative de l'anesthésie régionale à la TIVA et aux agents volatils. Dans les cas où les agents volatils sont préférés pour des applications cliniques, l'abandon de l'utilisation de desflurane et de $\mathrm{N}_{2} \mathrm{O}$ au profit du sévoflurane ou de l'isoflurane avec un débit de gaz frais (DGF) d'air/O $\mathrm{O}_{2}$ peut réduire les émissions de GES jusqu'à 20 fois par heure de concentration alvéolaire minimale. ${ }^{12}$ Dans plusieurs établissements de Vancouver par exemple, l'utilisation systématique du sévoflurane plutôt que du desflurane avec un faible DGF a entraîné une réduction de $66 \%$ des émissions de GES sur une période de cinq ans, ce qui équivaut à l'élimination des émissions annuelles produites par 1700 automobiles parcourant une moyenne de $22000 \mathrm{~km}$ par année. ${ }^{31}$

Une deuxième stratégie consiste à minimiser le DGF afin de réduire les émissions d'agents volatils pendant chaque phase de l'anesthésie. ${ }^{32} \mathrm{Si}$ une induction par inhalation est planifiée, comme c'est souvent le cas en anesthésie pédiatrique, la façon traditionnellement enseignée consiste à ventiler le patient au masque avec un DGF élevé et d'éteindre le vaporisateur lorsqu'on retire le masque pour l'intubation. Toutefois, une solution plus écoénergétique serait de fermer le DGF et de laisser le vaporisateur ouvert pendant l'intubation : de cette manière, la concentration de gaz est préservée dans le circuit. $^{32}$
Sinon, lorsqu'une TIVA est prévue pour la phase de maintien, même en pédiatrie, l'induction intraveineuse pourrait être préférable à une induction par inhalation, tant d'un point de vue clinique qu'environnemental. ${ }^{33} \mathrm{Si}$ le maintien par agent volatil est prévu après une induction intraveineuse de l'anesthésie, un DGF plus élevé est nécessaire pendant la phase initiale du maintien volatil afin de compenser l'absorption plus élevée de l'agent volatil par le patient. Il est cependant possible d'utiliser des débits plus faibles pendant cette phase en recourant au concept de «surpression». Les concentrations relativement stables de gaz pendant la phase de maintien sont une occasion idéale de recourir à une anesthésie en circuit fermé ou à faible DGF, en établissant des débits équivalents à la consommation d'oxygène du patient, ce qui pourrait être encore plus facile avec les appareils d'anesthésie modernes. Pendant le réveil de l'anesthésie, le gaspillage sera réduit si le DGF est maintenu à un faible niveau jusqu'à la fermeture du vaporisateur. ${ }^{32}$ Un inconvénient potentiel de DGF faibles tient aux besoins accrus pour un absorbant de $\mathrm{CO}_{2}$ dont l'empreinte concomitante doit encore être déterminée dans une étude d'ACV; toutefois, il est peu probable que cela contrebalance les avantages d'une réduction des émissions des agents volatils et du $\mathrm{N}_{2} \mathrm{O}$.

Même si de faibles DGF sont utilisés, d'importantes quantités de gaz sont libérées dans l'atmosphère. La réduction de ces émissions est l'objet d'une troisième stratégie. Les technologies de captage des gaz utilisent des filtres en zéolite de silice pour adsorber et piéger les gaz anesthésiques dans le système de récupération avant leur évacuation dans l'atmosphère, avec une efficacité de $\sim 75 \% .^{34}$ Les gaz sont piégés dans des bonbonnes et peuvent ensuite être récupérés et purifiés dans un établissement dédié. L'objectif ultime, soit de recycler et de revendre les agents volatils récupérés, est actuellement en attente d'approbation de Santé Canada. ${ }^{35}$ Malheureusement, cette technologie de captage n'adsorbe pas le $\mathrm{N}_{2} \mathrm{O}^{36}$

\section{Gaspillage médicamenteux}

On estime que 25-30 \% du budget destiné aux médicaments en anesthésie est régulièrement gaspillé. ${ }^{37}$ Une utilisation plus efficace des agents pharmaceutiques pourrait donc minimiser l'impact environnemental d'un tel gaspillage tout en ayant des avantages budgétaires considérables. Le propofol est le médicament le plus fréquemment distribué et gaspillé, avec un gaspillage pouvant atteindre $32-49 \% .^{28,37}$ De la même manière, les anesthésiologistes préparent souvent systématiquement les médicaments de réanimation cardiaque (tels que l'éphédrine, l'atropine et la phényléphrine) et les agents 
paralytiques, lesquels sont inutilisés jusqu'à $50 \%$ du temps. ${ }^{14,28,38}$ Étant donné que les anesthésiologistes ont appris à préparer ces médicaments, une approche moins dilapidatrice consisterait à garder des ampoules d'urgence et des seringues à portée de main de manière à ce qu'elles puissent être rapidement préparées au besoin. Une autre approche serait de demander aux pharmacies des hôpitaux de préparer des seringues préremplies de médicaments anesthésiques fréquemment utilisés, réduisant ainsi le gaspillage des médicaments tout en permettant d'importantes économies. ${ }^{39}$

L'ampleur du gaspillage médicamenteux est de plus en plus évidente alors qu'on observe la toxicité chronique et les effets environnementaux des agents pharmaceutiques dans nos sources d'eau. Par exemple, le propofol non métabolisé pose un risque environnemental particulier étant donné qu'il ne se dégrade pas, est hautement toxique pour les organismes aquatiques, est très mobile dans le sol et s'accumule dans les corps gras. ${ }^{28}$ C'est pourquoi l'élimination adéquate du propofol nécessite une incinération selon les indications du fabricant et les règles d'élimination des déchets pharmaceutiques. ${ }^{28}$

Les anesthésiologistes doivent faire attention aux médicaments qu'ils préparent et être conscients des implications environnementales et financières $\mathrm{du}$ gaspillage évitable. ${ }^{35}$

\section{Autres opportunités de réduction des déchets}

Plusieurs autres opportunités de réduction des déchets peuvent être facilement identifiées et nécessitent des travaux supplémentaires. Par exemple, nous pensons qu'en collaborant avec les autorités de réglementation, les fabricants et les fournisseurs, il sera possible de réduire la quantité de matériaux, d'emballages et d'inserts didactiques inutiles qu'on retrouve souvent dans les kits préemballés tels que les trousses de voies centrales, d'anesthésie rachidienne ou péridurale. Une autre source souvent oubliée de gaspillage en anesthésie réside dans la succion anesthésique, qui pourrait être éliminée en utilisant une tubulure chirurgicale avec un embout Yankauer pour aspirer les voies aériennes du patient lors de l'extubation.

\section{Réutiliser}

Les préoccupations quant aux risques d'infection ont entraîné le recours répandu aux matériels médicaux à usage unique, lesquels sont les grands responsables de l'augmentation des déchets en soins de santé des dernières années. Alors qu'il est indubitable que la sécurité des patients constitue une considération importante, ces inquiétudes doivent toutefois être sous-pesées par rapport aux impacts environnementaux sur la santé publique d'une augmentation des déchets issus des soins de santé. ${ }^{40}$ Ainsi, la méthodologie d'ACV a récemment été utilisée pour quantifier et comparer l'empreinte des alternatives réutilisables $v s$ à usage unique de produits anesthésiques fréquemment utilisés.

\section{Les dispositifs supraglottiques}

Les versions réutilisables et à usage unique des dispositifs supraglottiques tels que les masques laryngés LMA ${ }^{\circledR}$ (Teleflex Medical Canada Inc., Markham, ON) sont équivalentes en termes d'efficacité clinique et de facilité d'utilisation. Eckelman et coll. ont réalisé une ACV comparant 40 utilisations d'un masque laryngé Classic ${ }^{\mathrm{TM}}$ LMA à 40 utilisations uniques de masques laryngés Unique $^{\mathrm{TM}}$ LMA jetables en analysant plusieurs catégories d'impacts sur l'environnement et la santé humaine. ${ }^{13}$ Malgré la nécessité de nettoyer, de réemballer et de restériliser à plusieurs reprises les dispositifs réutilisables, l'analyse a clairement démontré leur impact environnemental moindre, en plus d'un coût par utilisation plus bas.

\section{Les textiles réutilisables}

Les blouses et champs réutilisables offrent d'importants avantages en matière de durabilité par rapport aux produits jetables, tant au niveau de l'utilisation des ressources en énergie, de la consommation d'eau, de l'empreinte carbone, des agents organiques volatils, et de la production de déchets solides, alors que leur coût, leur protection et leur confort demeurent comparables. ${ }^{41,42}$

Les circuits respiratoires

La réutilisation des circuits respiratoires en anesthésie est controversée. Plusieurs départements d'anesthésie réutilisent des circuits à utilisation unique avec un nouveau filtre au niveau de l'embranchement en $\mathrm{Y}$ du circuit pour chaque cas, alors que d'autres insistent pour utiliser un nouveau circuit pour chaque patient. Bien que les institutions canadiennes n'aient pas émis de recommandations à ce sujet, la Société d'anesthésiologie allemande appuie l'utilisation de circuits d'anesthésie pour une durée maximale de sept jours ${ }^{43}$ alors que l'Association des anesthésistes de Grande-Bretagne et d'Irlande recommande l'utilisation des circuits pour une journée entière, si un filtre approprié avec une efficacité de rétention des particules en suspension dans l'air > $99 \%$ est changé entre les patients. ${ }^{44}$ Les circuits ne sont changés entre les patients et jetés que s'ils sont visiblement contaminés ou utilisés pour des cas extrêmement 
infectieux, comme par exemple la tuberculose. En effet, les filtres bactériens jetables préviennent la transmission des bactéries en suspension dans l'air et protègent le circuit respiratoire d'une contamination bactérienne pour une durée maximale d'une semaine. ${ }^{45,46}$ Dès lors, bien qu'il soit nécessaire de réaliser des ACV pour comparer l'utilisation de filtres à haute efficacité, nous encourageons les anesthésiologistes à travailler de concert avec leur comité local de prévention des infections et de réutiliser les circuits d'anesthésie.

\section{Autres produits}

Des analyses de cycle de vie ont indiqué que les manches et lames réutilisables des laryngoscopes, ${ }^{15}$ les contenants pour objets tranchants, ${ }^{47}$ mais non les trousses pour voies centrales ${ }^{48}$ ont un impact environnemental réduit par rapport à leurs pendants à usage unique. Globalement, ces études indiquent qu'alors que les options réutilisables semblent être préférables, de telles comparaisons sont toujours spécifiques au produit et au contexte. ${ }^{49}$ Des ACV comparatives doivent par conséquent être réalisées lorsque de telles données ne sont pas disponibles, comme par exemple dans le cas de lames de vidéolaryngoscope réutilisables $v s$ jetables, ou d'un matelas chauffant à circulation d'eau réutilisable vs une couverture chauffante à air à usage unique.

\section{Retraitement des dispositifs à usage unique}

L'étiquette «utilisation unique » sur les dispositifs médicaux est souvent apposée à la discrétion du fabricant et pourrait être davantage influencée par un marketing créatif que par des données probantes rigoureuses. Dans l'optique de réduire les coûts et d'améliorer la gestion des déchets, le retraitement de bon nombre de dispositifs à usage unique est devenu systématique dans certains centres. ${ }^{50} \mathrm{Ce}$ type de retraitement peut être organisé au sein même d'un hôpital ou sous contrat par des tierces parties, ce qui permet aux hôpitaux de «racheter» les dispositifs retraités à un coût nettement plus bas. ${ }^{50}$ Une liste des dispositifs à usage unique traités peut être obtenue de l'Association des entreprises de traitement des dispositifs médicaux (Association of Medical Device Reprocessors) et inclut des brassards de tensiomètre, des tourniquets, des capteurs d'oxymétrie de pouls et des masques d'anesthésie. ${ }^{50,51}$

\section{Risque d'infection}

De rares études sur le risque d'infection associé à la réutilisation de produits ont indiqué qu'un tel risque était présent lors de la réutilisation de matériel complexe défectueux (par ex. des bronchoscopes flexibles) ou des processus de nettoyage mal appliqués. ${ }^{52-54}$ Lorsqu'ils surviennent, ces incidents de transmission de maladie peuvent être catastrophiques pour les patients et les familles touchés. C'est pourquoi des contrôles d'audit systématiques sont nécessaires afin de quantifier le risque global et spécifique au matériel du retraitement et de la réutilisation et de le soupeser par rapport au risque individuel potentiel pour les patients ainsi qu'au risque posé à la santé publique par l'augmentation constante des déchets médicaux. ${ }^{40}$

\section{Recycler et trier}

Les salles d'opération génèrent de $20 \%$ à $33 \%$ des déchets hospitaliers totaux, ${ }^{55}$ les déchets liés à l'anesthésie représentant jusqu'à $25 \%$ de tous les déchets générés pendant une chirurgie. ${ }^{56}$ Les déchets médicaux sont traditionnellement divisés en deux catégories: les déchets biomédicaux et les déchets généraux. Les déchets biomédicaux peuvent être contaminés par des liquides organiques et peuvent potentiellement causer des maladies. Leur élimination coûte beaucoup plus cher et a un impact environnemental plus important étant donné qu'ils doivent être incinérés ou stérilisés avant d'être envoyés au site d'enfouissement.

Selon les experts, les déchets biomédicaux ne devraient pas constituer plus de $15 \%$ du flux total de déchets d'une institution. Malheureusement, plus de $70 \%$ des déchets généraux de SOP sont potentiellement recyclables mais sont incorrectement jetés en tant que déchets biomédicaux, entraînant des coûts d'élimination plus élevés ainsi que des effets délétères pour l'environnement. ${ }^{57}$ Wyssusek et coll. ont démontré que, après avoir introduit un programme sophistiqué de tri des déchets en SOP, les déchets biomédicaux ont été réduits à $18 \%$ des déchets totaux de SOP, ce qui s'est traduit par une réduction de $80 \%$ des coûts de gestion des déchets. ${ }^{57}$ Un exemple particulièrement pertinent pour l'anesthésie d'une telle stratégie de tri des déchets est le recours à des contenants à objets tranchants stérilisés à l'autoclave avant leur élimination à des coûts financiers et environnementaux considérables. Le contenu de tels contenants devrait se limiter aux objets tranchants ou perçants - comme les aiguilles, mais pas les seringues qui y sont attachées.

Le coût de traitement à des fins de recyclage est moins élevé que le coût à des fins d'élimination des déchets solides, et on estime qu'environ $60-70 \%$ des déchets de l'anesthésie générale pourraient être recyclés. ${ }^{57,58}$ Cela est dû aux ententes selon lesquelles les hôpitaux doivent payer les entreprises de gestion des déchets pour qu'ils retirent leurs déchets, mais qu'ils peuvent vendre leur recyclage à des entreprises. Ainsi, un recyclage minutieux pourrait 
Tableau 3 Déchets anesthésiques potentiellement recyclables

\begin{tabular}{ll}
\hline Plastiques* & Papier \\
\hline Emballages d'instruments chirurgicaux (y compris emballage bleu) & $\begin{array}{c}\text { Carton pour boîte } \\
\text { Inserts en papier } \\
\text { Couvertures chauffantes à air pulsé }\end{array}$ \\
$\begin{array}{c}\text { Ampoullages en papier } \\
\text { déchirables }\end{array}$ \\
Sacs et tubulures pour liquides intraveineux non contaminés \\
Masques à oxygène et tubulures \\
Tubulures pour l'aspiration \\
$\begin{array}{l}\text { Seringues non contaminées } \\
\text { Emballages en plastique dur (plateaux de matériel d'intervention, par ex. plateaux pour voies } \\
\text { centrales) }\end{array}$ \\
\hline
\end{tabular}

*Les plastiques recyclables comprennent le polypropylène, le polyéthylène, le polyuréthane et le polychlorure de vinyle. La liste des plastiques recyclables est tirée de McGain et coll..$^{59}$

entraîner d'importantes économies, en réduisant d'autant plus le coût des déchets solides grâce à des rabais potentiellement négociés avec les entreprises de recyclage industriel. Cependant, malgré les avantages environnementaux et financiers évidents du recyclage et un intérêt prononcé des anesthésiologistes pour cette modalité, plusieurs sondages récents indiquent que moins d'un tiers des anesthésiologistes recyclent au travail. ${ }^{7}$ Certains obstacles tels que le manque de soutien des directions d'hôpitaux ainsi qu'une information et une formation inadéquates pourraient jouer un rôle dans cet écart. ${ }^{7}$ Un autre obstacle majeur au captage complet des matériaux recyclables de la SOP a trait aux inquiétudes des entreprises de recyclage quant à la contamination infectieuse des matériaux et à l'exposition de leurs employés aux liquides organiques. ${ }^{37}$ Une façon de surmonter ces préoccupations serait de récolter les composantes recyclables de l'emballage pendant la phase de préparation du cas, avant que le patient n'entre en SOP. ${ }^{35}$ Le Tableau 3 donne quelques exemples de matériaux liés à l'anesthésie potentiellement recyclables; toutefois, les sous-ensembles spécifiques de matériaux recyclables varient considérablement, non seulement d'une institution à l'autre, mais également d'un pays à un autre. ${ }^{59,60}$ Nous encourageons les lecteurs à communiquer avec leur représentant local en charge du recyclage pour des informations plus détaillées.

\section{Prochaines étapes}

Les initiatives futures devraient s'employer à unifier la communauté anesthésique canadienne vers un but commun: réduire l'empreinte écologique de notre spécialité. La participation à des groupes d'intérêt spécial ou à des sous-sections des organismes professionnels nationaux ou internationaux (comme par exemple la
Section pour la durabilité de l'environnement de la Société canadienne des anesthésiologistes) pourrait faciliter la génération de données collaboratives, la recherche, la mise au point de directives et les efforts de transmission des connaissances. Ces organismes pourraient également jouer un rôle important dans les campagnes de défense d'intérêts politiques, en travaillant pour faire de la durabilité environnementale une des mesures de qualité utilisées dans la certification des hôpitaux. En outre, les cliniciens devraient jouer un rôle éducationnel en façonnant les priorités des générations futures de médecins, soit en intégrant des informations touchant à la durabilité environnementale dans leurs enseignements didactiques, ou en démontrant par leurs gestes une pratique durable. $^{61}$

\section{Conclusion}

Les soins de santé sont non seulement victimes des impacts négatifs du réchauffement climatique et de la dégradation de l'environnement, mais ils y contribuent également de façon significative. Les anesthésiologistes occupent une position unique pour devenir les champions de la durabilité environnementale du système de soins de santé par des pratiques fondées sur des données probantes, tout en renforçant la qualité et la durabilité financière des soins. Afin de poursuivre notre mission de fourniture de soins d'excellence à nos patients individuels dans les générations à venir, nous devons saisir l'occasion d'être les gardiens du système de santé qui nous a été confié.

\section{Cas clinique}

Vous êtes sur le point d'anesthésier un enfant de trois ans en bonne santé devant subir une réparation d'hernie 
inguinale. Vous pensez aux diverses stratégies qui peuvent être utilisées dans le cadre de la prise en charge anesthésique pour réduire l'impact environnemental de l'anesthésie.

\section{Directives pour compléter le module de développement professionnel continu (DPC) :}

1. Lisez cet article et les références en gras.

2. Allezà: https://www.cas.ca/fr/education-fr/developpementprofessionnel-continu afin d'accéder à notre système de gestion de l'apprentissage, enregistrez-vous et choisissez le module actuel (La médecine périopératoire durable : quelques stratégies simples pour la pratique de l'anesthésie). Votre nom d'utilisateur correspond à l'adresse électronique enregistrée dans le répertoire des membres et votre mot de passe correspond à votre identifiant de la Société canadienne des anesthésiologistes. Ce module est agréé pour trois ans. Vous pouvez retrouver la période exacte d'agrément sur le site internet de la SCA et dans le système de gestion de l'apprentissage.

3. Répondez aux questions à choix multiples portant sur le cas clinique.

4. Une fois que vous aurez saisi toutes vos réponses, vous aurez accès aux explications d'experts pour tous les choix possibles.

5. Les participants peuvent déclarer jusqu'à quatre heures de DPC en vertu de la section 3 du Programme de MDC du Collège royal des médecins et chirurgiens du Canada.

Conflicts of interest Drs Petre and Malherbe have no conflicts of interest.

Funding statement None.

Editorial responsibility :This submission was handled by Dr. Adriaan Van Rensburg, CPD Editor, Canadian Journal of Anesthesia.

Conflit d'intérêt Les Drs Petre et Malherbe n'ont pas de conflit d'intérêt.

Déclaration de financement: Aucune.

Responsabilité éditoriale Cet article a été traité par Dr Adriaan Van Rensburg, rédacteur des DPC, Journal canadien d'anesthésie.

\section{References}

1. Watts N, Amann M, Ayeb-Karlsson $S$, et al. The Lancet Countdown on health and climate change: from 25 years of inaction to a global transformation for public health. Lancet 2018; 392: 581-630.

2. Costello A, Abbas M, Allen A, et al. Managing the health effects of climate change: Lancet and University College London Institute for Global Health Commission. Lancet 2009; 373: 1693-733.

3. Eckelman MJ, Sherman J. Environmental impacts of the U.S. Health Care System and effects on public health. PLoS One 2016; https://doi.org/10.1371/journal.pone.0157014.

4. Eckelman MJ, Sherman JD, MacNeill AJ. Life cycle environmental emissions and health damages from the Canadian healthcare system: an economic-environmentalepidemiological analysis. PLoS Med 2018; . https://doi.org/10. 1371/journal.pmed.1002623.

5. Masson-Delmentte V, Zhai P, Portner HO, et al. IPCC, 2018: Summary For Policymakers. An IPCC Special Report on the impacts of global warming of $1.5^{\circ} \mathrm{C}$ above pre-industrial levels and related global emission pathways, in the context of strengthening the global response to the threat of climate change, sustainable development, and efforts to eradicate poverty. Available from URL: https://www.ipcc.ch/site/assets/ uploads/sites/2/2019/05/SR15_SPM_version_report_LR.pdf (accessed February 2020).

6. MacNeill AJ, Lillywhite R, Brown CJ. The impact of surgery on global climate: a carbon footprinting study of operating theatres in three health systems. Lancet Planet Health 2017; 1: e381-8.

7. Petre MA, Bahrey L, Levine M, van Rensburg A, Crawford M, Matava $C$. A national survey on attitudes and barriers on recycling and environmental sustainability efforts among Canadian anesthesiologists: an opportunity for knowledge translation. Can J Anesth 2018; 66: 272-86.

8. Thiel CL, Eckelman M, Guido R, et al. Environmental impacts of surgical procedures: life cycle assessment of hysterectomy in the United States. Environ Sci Technol 2015; 49: 1779-86.

9. Naylor C, Appleby J. Sustainable health and social care: Connecting environmental and financial performance. The

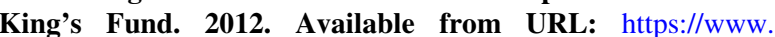
kingsfund.org.uk/publications/sustainable-health-and-social-care (accessed February 2020).

10. Rebitzer $G$, Ekvall T, Frischknecht $R$, et al. Life cycle assessment part 1: framework, goal and scope definition, inventory analysis, and applications. Environ Int 2004; 30: 701-20.

11. Pennington DW, Potting J, Finnveden G, et al. Life cycle assessment Part 2: Current impact assessment practice. Environ Int 2004; 30: 721-39.

12. Sherman J, Le C, Lamers V, Eckelman M. Life cycle greenhouse gas emissions of anesthetic drugs. Anesth Analg 2012; 114: 1086-90.

13. Eckelman M, Mosher M, Gonzalez A, Sherman J. Comparative life cycle assessment of disposable and reusable laryngeal mask airways. Anesth Analg 2012; 114: 1067-72.

14. Atcheson $C L$, Spivack $J$, Williams $R$, Bryson EO. Preventable drug waste among anesthesia providers: opportunities for efficiency. J Clin Anesth 2016; 30: 24-32.

15. Sherman JD, Raibley LA 4th, Eckelman MJ. Life cycle assessment and costing methods for device procurement: comparing reusable and single-use disposable laryngoscopes. Anesth Analg 2018; 127: 434-43.

16. McGain F, Naylor C. Environmental sustainability in hospitals - a systematic review and research agenda. J Health Serv Res Policy 2014; 19: 245-52.

17. Wernet $G$, Conradt $S$, Isenring HP, Jiménez-González $C$, Hungerbühler $K$. Life cycle assessment of fine chemical production: a case study of pharmaceutical synthesis. Int J Life Cycle Assess 2010; 15: 294-303. 
18. Johnson SW. Summarizing green practices in U.S. hospitals. Hosp Top 2010; 88: 75-81.

19. Lewis D, Tranter G, Axford AT. Use of videoconferencing in Wales to reduce carbon dioxide emissions, travel costs and time. J Telemed Telecare 2009; 15: 137-8.

20. Masino C, Rubinstein E, Lem L, Purdy B, Rossos PG. The impact of telemedicine on greenhouse gas emissions at an academic health science center in Canada. Telemed J E Health 2010; 16: 973-6.

21. Turley M, Porter C, Garrido T, et al. Use of electronic health records can improve the health care industry's environmental footprint. Health Aff (Millwood) 2011; 30: 938-46.

22. Cosford P. 'Partners in clime': sustainable development and climate change - what can the National Health Service do? Public Health 2009; 123: e1-5.

23. Mejia EA, Sattler B. Starting a health care system green team. AORN J 2009; 90: 33-40.

24. Ryan-Fogarty $Y$, O'Regan B, Moles $R$. Greening healthcare: systematic implementation of environmental programmes in a university teaching hospital. J Clean Prod 2016; 126: 248-59.

25. Andersen MP, Nielsen OJ, Wallington T, Karpichev B, Sander $S P$. Assessing the impact on global climate from general anesthetic gases. Anesth Analg 2012; 114: 1081-5.

26. Ryan SM, Nielsen CJ. Global warming potential of inhaled anesthetics: application to clinical use. Anesth Analg 2010; 111: $92-8$.

27. Özelsel TJ, Sondekoppam RV, Ip VH, Tsui BC. Re-defining the $3 R$ 's (reduce, refine, and replace) of sustainability to minimize the environmental impact of inhalational anesthetic agents. Can $\mathrm{J}$ Anesth 2019; 66: 249-54.

28. Mankes RF. Propofol wastage in anesthesia. Anesth Analg 2012; 114: 1091-2.

29. Ip VH, Sondekoppam RV, Özelsel TJ, Tsui B. How I Do It: Edmonton Perspectives in Providing Sustainable Anesthesia. ASRA News 2018 [cited 2019 Nov 11]. Available from URL: https://www.asra.com/asra-news/article/146/how-i-do-itedmonton-perspectives-in-pro (accessed February 2020).

30. Özelsel T, Sondekoppam RV, Ip VH, Tsui BC. Coming of age for "green" anesthesia: the leading role of regional anesthesia. Reg Anesth Pain Med 2017; 42: 799-800.

31. Alexander R, Poznikoff A, Malherbe S. Greenhouse gases: the choice of volatile anesthetic does matter. Can J Anesth 2018; 65: 221-2.

32. Feldman JM. Managing fresh gas flow to reduce environmental contamination. Anesth Analg 2012; 114: 1093-101.

33. Sommerfield D, von Ungern-sternberg BS. The mask or the needle? Which induction should we go for? Curr Opin Anaesthesiol 2019; 32: 377-83.

34. Doyle DJ, Byrick R, Filipovic D, Cashin F. Silica zeolite scavenging of exhaled isoflurane: a preliminary report. Can J Anesth 2002; 49: 799-804.

35. Axelrod D, Bell C, Feldman J, et al. Greening the Operating Room and Perioperative Arena: Environmental Sustainability for Anesthesia Practice. American Society of Anesthesiologists. Available from URL: https://www.asahq. org/about-asa/governance-and-committees/asa-committees/ committee-on-equipment-and-facilities/environmentalsustainability/greening-the-operating-room (accessed February 2020).

36. Sherman JD, Barrick B. Total intravenous anesthetic versus inhaled anesthetic: pick your poison. Anesth Analg 2019; 128: $13-5$.

37. Gillerman $R G$, Browning $R A$. Drug use inefficiency: a hidden source of wasted health care dollars. Anesth Analg 2000; 91: 921-4.
38. Lejus $C$, Blanloeil $Y$, Oudot $M$, et al. Atropine and ephedrine: a significant waste in the operating theatre. Anaesthesia 2012; 67: 300-1.

39. Fortier CR, Abernathy JH, Shepherd M, Guidry OF. Conversion to pre-filled medication syringes reduces medication waste and costs. Anesth Analg 2011; 112: S124 (abstract).

40. Sherman JD, Hopf $H W$. Balancing infection control and environmental protection as a matter of patient safety: the case of laryngoscope handles. Anesth Analg 2018; 127: 576-9.

41. Overcash M. A comparison of reusable and disposable perioperative textiles: sustainability state-of-the-art 2012. Anesth Analg 2012; 114: 1055-66.

42. Vozzola E, Overcash M, Griffing E. Environmental considerations in the selection of isolation gowns: a life cycle assessment of reusable and disposable alternatives. Am J Infect Control 2018; 46: 881-6.

43. Kramer A, Kranabetter $R$, Rathgeber J, et al. Infection prevention during anaesthesia ventilation by the use of breathing system filters (BSF): joint recommendation by German Society of Hospital Hygiene (DGKH) and German Society for Anaesthesiology and Intensive Care (DGAI). GMS Krankenhhyg Interdiszip 2010; . https://doi.org/10.3205/dgkh000156.

44. Association of Anaesthetists of Great Britain and Ireland. Infection control in anaesthesia. Anaesthesia 2008; 63: 1027-36.

45. Dubler S, Zimmermann S, Fischer $M$, et al. Bacterial and viral contamination of breathing circuits after extended use - an aspect of patient safety? Acta Anaesthesiol Scand 2016; 60: 1251-60.

46. McGain F, Algie CM, O'Toole J, et al. The microbiological and sustainability effects of washing anaesthesia breathing circuits less frequently. Anaesthesia 2014; 69: 337-42.

47. Grimmond T, Reiner $S$. Impact on carbon footprint: a life cycle assessment of disposable versus reusable sharps containers in a large US hospital. Waste Manag Res 2012; 30: 639-42.

48. McGain F, McAlister S, McGavin A, Story D. A life cycle assessment of reusable and single-use central venous catheter insertion kits. Anesth Analg 2012; 114: 1073-80.

49. McGain F, Story D, Lim T, McAlister S. Financial and environmental costs of reusable and single-use anaesthetic equipment. Br J Anaesth 2017; 118: 862-9.

50. Polisena J, Hailey D, Moulton K, et al. Reprocessing and reuse of single-use medical devices: a national survey of Canadian acutecare hospitals. Infect Control Hosp Epidemiol 2008; 29: 437-9.

51. Unger $S$, Landis A. Assessing the environmental, human health, and economic impacts of reprocessed medical devices in a Phoenix hospital's supply chain. J Clean Prod 2016; 112: 19952003.

52. Negri de Sousa AC, Levy CE, Freitas MI. Laryngoscope blades and handles as sources of cross-infection: an integrative review. $\mathbf{J}$ Hosp Infect 2013; 83: 269-75.

53. Rutala WA, Weber DJ. New developments in reprocessing semicritical items. Am J Infect Control 2013; 41(5 Suppl): S60-6.

54. Ofstead CL, Quick MR, Wetzler HP, et al. Effectiveness of reprocessing for flexible bronchoscopes and endobronchial ultrasound bronchoscopes. Chest 2018; 154: 1024-34.

55. Kagoma Y, Stall N, Rubinstein E, Naudie D. People, planet and profits: the case for greening operating rooms. CMAJ 2012; 184: 1905-11.

56. McGain FM, Hendel SA, Story DA. An audit of potentially recyclable waste from anaesthetic practice. Anaesth Intensive Care 2009; 37: 820-3.

57. Wyssusek KH, Foong WM, Steel C, Gillespie BM. The Gold in garbage: implementing a waste segregation and recycling initiative. AORN J 2016; 103(316): e1-8. 
58. McGain F, White S, Mossenson S, Kayak E, Story D. A Survey of anesthesiologists' views of operating room recycling. Anesth Analg 2012; 114: 1049-54.

59. McGain F, Clark M, Williams T, Wardlaw T. Recycling plastics from the operating suite. Anaesth Intensive Care 2008; 36: 913-4.

60. Gaiser RR, Cheek TG, Gutsche BB. Glass recycling in the labour suite is environmetally sound and economical. $\mathrm{Br} \mathrm{J}$ Anaesth 2004; 92: 584-6.
61. Shelton CL, McBain SC, Mortimer F, White SM. A new role for anaesthetists in environmentally-sustainable healthcare. Anaesthesia 2019; 74: 1091-4.

Publisher's Note Springer Nature remains neutral with regard to jurisdictional claims in published maps and institutional affiliations. 